\title{
Reproductive biology of Bryconamericus iheringii (Ostariophysi: Characidae) from rio Vacacaí, RS, Brazil
}

\author{
Vinicius Renner Lampert, Marco Aurélio Azevedo \\ and Clarice Bernhardt Fialho
}

\begin{abstract}
In this paper we describe some aspects of the reproduction and development of secondary sexual characters of Bryconamericus iheringii, based on the analysis of 194 females and 210 males collected monthly in the rio Vacacaí (30²1'34"S and 54'18'48"W), from April 2001 to March 2002. The reproductive period occurred from September to January (spring and summer in the Southern Hemisphere), as described for other characids of the same area. The absolute fecundity mean was $933.71 \pm 303.10$ oocytes, and the relative fecundity mean was $0.36 \pm 0.08$ oocytes per mg of total weight, being the species a multiple spawner. There was no correlation between the values of GSI and variation of biotic (stomach repletion and hepatosomatic indexes) and abiotic data (rainfall, day length and temperature) but we suggest that these factors can influence the reproduction of the species acting as "starters" of the beginning of gonadal maturation. Fin-ray hooks consist in a sexually dimorphic character of the species. Well developed hooks were found mainly in mature males, during the reproductive period and in the largest individuals.
\end{abstract}

Neste trabalho são descritos aspectos da reprodução e do desenvolvimento de caracteres sexuais secundários em Bryconamericus iheringii. Foram analisados 194 fêmeas e 210 machos coletados mensalmente no rio Vacacaí (30²1'34”S e $54^{\circ} 18^{\prime} 48^{\prime}$ 'W), de abril de 2001 a março de 2002. O período reprodutivo ocorreu de setembro a janeiro (primavera e verão no hemisfério sul), como descrito para outros caracídeos da mesma região. A fecundidade absoluta média foi de 933,71 $\pm 303,10$ ovócitos e a fecundidade relativa média foi de $0,36 \pm 0,08$ ovócitos por mg de peso total, sendo a desova do tipo parcelada. Não houve correlação entre os valores de IGS e a variação dos dados bióticos (índices de repleção e hepatossomático) e abióticos (pluviosidade, fotoperíodo e temperatura) mas sugere-se que estes fatores possam influenciar na reprodução da espécie, atuando como desencadeadores do início da maturação gonadal. Ganchos nas nadadeiras ventrais e anal dos machos consistiram em caracteres de dimorfismo sexual da espécie. Ganchos bem desenvolvidos são encontrados principalmente em machos maduros, durante o período reprodutivo e nos maiores indivíduos.

Key words: Reproductive period, fecundity, spawning type, fin-ray hooks.

\section{Introduction}

The family Characidae has 952 valid species and 400 still not described, amounting 1352 species. Bryconamericus is one of the 88 genera listed as incertae sedis, with 51 described species (Reis et al., 2003). Bryconamericus includes basically small-sized species, usually not exceeding $10 \mathrm{~cm}$ in length, living in different environments and showing omnivorous behavior, serving as an important food source for piscivores fishes (Britski et al., 1988). According to Vari \& Siebert (1990), species of Bryconamericus are distributed in a diversity of freshwater ecosystems in Central and South Americas, from Costa Rica to the Western Argentina, on both sides of the Andes cordillera.
According to Silva (1998) fifteen species of Bryconamericus are found in Southern and Southeastern Brazil.

Bryconamericus iheringii occurs in the laguna dos Patos and rio Uruguay drainages, south Brazil, Uruguay and Argentina. Although common, few studies were conducted regarding aspects of its reproduction in these environments. Reproduction represents one of the most important aspects of the biology of a species, because the maintenance of viable populations depends of its success (Suzuki \& Agostinho, 1997). In the same way, there are few studies reporting the development of secondary sexual characters in fish, although it is known that males of most characins species have hooks on the fins (Malabarba \& Weitzman, 2003). Aspects of the

Departamento de Zoologia, Laboratório de Ictiologia, Universidade Federal do Rio Grande do Sul, Av. Bento Gonçalves, 9500, 90540-000 Porto Alegre, RS, Brazil. e-mail: vlampert@ufrgs.br 
development of these structures and their relationship with gonadal maturation and individual's size are still unknown. The aim of this paper is to describe the reproductive period, fecundity and spawning of $B$. iheringii in the rio Vacacaí, Rio Grande do Sul state, and to verify possible relationships between the reproduction and biotic/abiotic factors. Furthermore, the paper aims also to describe the occurrence of secondary sexual characters and the possible relationships of these with the reproductive period, gonadal maturation and individual body length.

\section{Material and Methods}

Samples were taken monthly between April 2001 and March 2002 in the rio Vacacaí (30²1'34"S and 54¹8'48"W) near São Gabriel, RS, Brazil, using seine net (5 mm mesh size). Water temperature was registered on the field, the day length was obtained with a GPS and rainfall data were provided by the 8th District of Meteorology of Porto Alegre through the Climatologic Station of Santa Maria, close to our sampling site. Collected fish were fixed in $10 \%$ formalin in the field and, in laboratory, specimens were measured (Standard Length $\mathrm{SL}, \mathrm{mm}$ ) and weighted (Total Weight - Wt, g). Voucher specimens were catalogued in the fish collection of the Universidade Federal do Rio Grande do Sul (UFRGS 6692).

Fishes were dissected to identify sex and gonadal development. Fish gonads, stomachs and livers were weighted and preserved in alcohol 70\%. Gonad development was macroscopically characterized as follows:

Stage I - immature (IMT) - small, filamentous, translucent and undeveloped testis; small ovaries, generally transparent, with undeveloped oocytes.

Stage II - maturing (MTG) - solid and compact testis with milky coloration having $1 / 3$ to $2 / 3$ of the size of mature gonads; ovaries with oocytes of different sizes with yellowish coloration.

Stage III - mature (MAT) - big testis with white coloration, sometimes yellowish, occupying about $1 / 4$ of the visceral cavity; ovaries with well developed oocytes with yellow or orange coloration.

Stage IV - spawning (SPW) - not identified in males; ovaries slightly flaccid and presence of reserve and yolky oocytes.

Stage V - spent (SPT) - reduced and flaccid testis; ovaries with a disarranged aspect presenting small oocytes and absence of yolky oocytes.

Hooks on pelvic and anal fins were observed through a stereomicroscope and were classified into four degrees of development: absent - without hooks on fins; less developed - hooks not much salient, in small number, visible mainly on the pelvic fins; developed - larger hooks, in large number, observed on anal and pelvic fins; well developed - big, numerous and slightly curved hooks, easily identified in anal and pelvic fins.

From the obtained data, the Gonadosomatic Index - GSI (Vazzoler, 1996), Stomach Repletion Index - SRI and
Hepatosomatic Index - HSI (Santos, 1978) were calculated, representing the percentage of the organ weight in relation to total fish weight. The reproductive period was determined through the analysis of the monthly variation of GSI mean values as well as analyzing the relative frequencies of gonadal maturation stages along the sampling period. The nonparametric Spearman Rank correlation was applied between the monthly mean values of GSI and the monthly values of SRI, HSI, rainfall, day length and temperature to verify possible relationships between reproduction and biotic and abiotic factors. The ovaries of 14 mature females ranging from 32.97 to $49.55 \mathrm{~mm}$ SL were immersed in Gilson's solution to estimate absolute fecundity of the species, according to Vazzoler (1996). After the oocytes were released from the ovarian tissue, all yolky oocytes were counted under a stereomicroscope. Relative fecundity was calculated counting the number of oocytes per milligram of female's total body weight, as suggested by Adebisi (1987). The values of total fecundity were regressed against standard length, total weight and gonads weight to verify how they are related. The spawning type was established through the analysis of 31 ovaries representing the different gonadal maturation stages. In each ovary, 150 oocytes were sampled and were measured considering their largest diameter (Vazzoler, 1996). Measurements were taken using a scale in the stereomicroscope ocular and the oocyte diameters were grouped in intervals of $0.05 \mathrm{~mm}$ class. The variation of frequencies of each oocyte diameter interval class was analyzed by gonadal maturation stages (Vazzoler, 1996). The frequency of hooks was compared to the frequency of gonadal maturation stages, months and standard length classes. Nine standard length classes were established, with $4 \mathrm{~mm}$ intervals: Class 1 - 17.9-21.9 mm; Class 2 -21.9-25.9 mm; Class 3 - 25.9-29.9 mm; Class 4 - 29.9-33.9 $\mathrm{mm}$; Class 5 - 33.9-37.9 mm; Class 6 - 37.9-41.9 mm; Class 7 41.9-45.9 mm; Class 8-45.9-49.9 mm; Class 9-49.9-53.9 mm.

\section{Results}

We analyzed 194 females (19.7-54.6 mm SL) and 210 males (17.9-51.5 mm SL) of B. iheringii. The highest GSI values in both sexes were observed between August and November (Fig.1).

The relative frequencies of gonadal maturation stages (Fig. 2a-b) showed the presence of mature and spent females between August and March, with higher frequencies in September and January, indicating the reproductive period of the species. Immature and maturing males appeared in all months. Mature males were absent in February and March, having the highest frequency in October. The spent individuals occurred in April, January, February and March.

The monthly SRI means for females and males showed higher values in August, January and February, before and after the peaks of GSI. The variation of HSI mean values for females showed stable values between June and September and a decrease in October, after the peak of the GSI mean. 


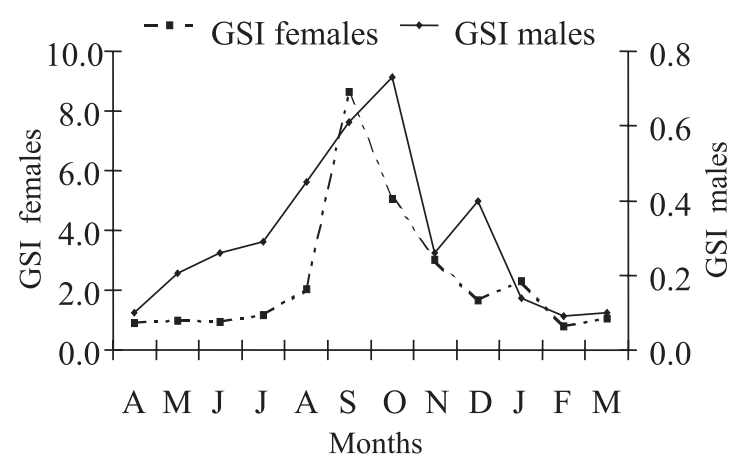

Fig. 1. Monthly variation of the mean values of the gonadosomatic index (GSI) on females and males of Bryconamericus iheringii from rio Vacacaí, RS, Brazil, from April 2001 through March 2002.

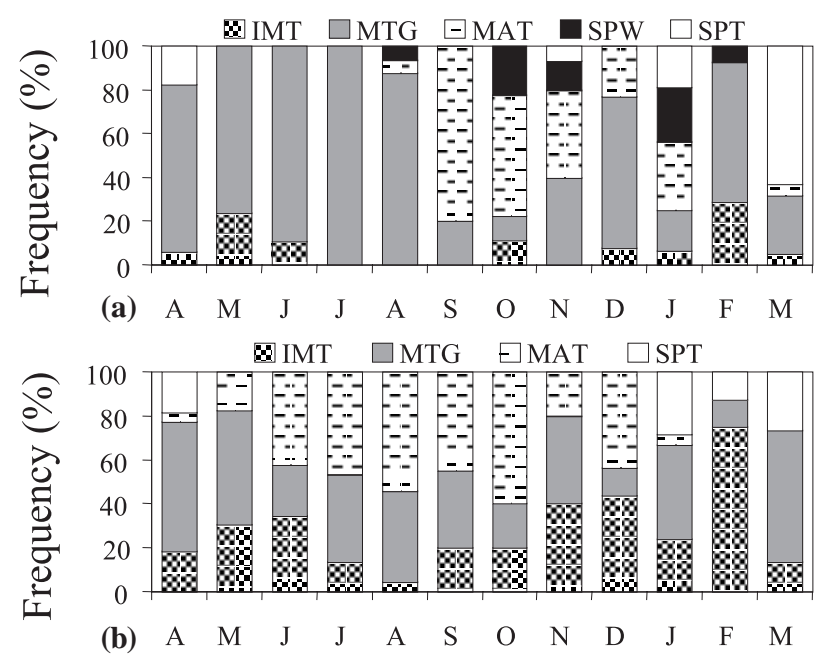

Fig. 2. Frequency of occurrence of gonadal maturation stages for females (a) and males (b) of Bryconamericus iheringii from rio Vacacaí, RS, Brazil, from April 2001 through March 2002. $\mathrm{IMT}=$ immature; $\mathrm{MTG}=$ maturing; $\mathrm{MAT}=$ mature; $\mathrm{SPW}$ = spawning; $\mathrm{SPT}=$ spent.
Despite the variability in rainfall along the year, the higher GSI values occurred in September and October, the period of highest rainfall. Water temperature was higher between October and February (Table 1), coinciding with the reproductive period. It may suggest that reproduction is associated with temperature rise. The non-parametric Spearman correlation, however, did not show statistical significance between the GSI of both sexes and the biotic and abiotic factors (Table 2).

The absolute fecundity of $B$. iheringii ranged from 370 to 1600 oocytes, with a mean of $933.71 \pm 303.10$ oocytes. The mean relative fecundity was $0.36 \pm 0.08$ oocytes $/ \mathrm{mg}$ of total weight. The relationships between absolute fecundity and standard length and absolute fecundity and total weight were adjusted to a potential equation $\left(\mathrm{y}=0.0704 \mathrm{x}^{2,4755} ; \mathrm{r}=\right.$ 0.78 and $y=446.96 x^{0,7279} ; r=0.81$; respectively), while the relationship of absolute fecundity and gonads weight was adjusted to a linear equation $(y=2072.4 x+326.67 ; \mathrm{r}=0.95)$.

Small diameter oocytes had a high frequency in all gonadal maturation stages (Fig. 3), while several modes of greater diameter oocytes occurred in the mature stage. They represent reserve oocytes and oocytes that will be released along the reproductive period. The presence of both developmental stages of oocytes as well as several modes of greater diameter oocytes is indicative that the species is a multiple spawner. In the spent stage, there are no large diameter oocytes, suggesting spawning is finished.

The frequency of occurrence of hooks on pelvic and anal fins was related to gonadal maturation stages of males (Fig. 4a) showing that $88 \%$ of the mature males presented well developed hooks; maturing males presented less developed and developed hooks, and, in most immature males, the hooks were absent. Males with well developed hooks were more frequent between July and December (Fig. 4b), with the highest frequency in October (60\%), which coincides with the highest mean value of GSI. Males with developed hooks as well as those of the absent category occurred throughout the year. Individuals with less developed hooks did not appear only in July, but were more frequent in April and May (Fig. 4b).

Table 1. Monthly variation in the mean values of GSI (gonadosomatic index), SRI (stomach repletion index), HSI (hepatosomatic index) ( \pm SD) and number of individuals $(\mathrm{N})$ of females and males of Bryconamericus iheringii from rio Vacacaí, RS, Brazil, and rainfall $(\mathrm{mm})$, day length (min) and water temperature $\left({ }^{\circ} \mathrm{C}\right)$ data (April 2001 to March 2002).

\begin{tabular}{|c|c|c|c|c|c|c|c|c|c|c|}
\hline Months & GSI 우 & SRI 우 & HSI 우 & $\mathrm{N}$ 우 & GSI $\sigma^{x}$ & SRI $0^{x}$ & $\mathrm{No}$ & Rainfall & Day length & Water Temp \\
\hline APR & $0.91 \pm 0.28$ & $3.11 \pm 0.76$ & $0.99 \pm 0.37$ & 17 & $0.09 \pm 0.12$ & $3.06 \pm 0.63$ & 22 & 249.6 & 696 & 21.6 \\
\hline MAY & $0.98 \pm 0.27$ & $2.79 \pm 0.86$ & $1.59 \pm 0.70$ & 17 & $0.21 \pm 0.08$ & $3.85 \pm 4.97$ & 23 & 56.9 & 641 & 15.5 \\
\hline JUN & $0.95 \pm 0.20$ & $2.72 \pm 0.46$ & $1.29 \pm 0.28$ & 19 & $0.26 \pm 0.13$ & $2.69 \pm 0.77$ & 26 & 179.5 & 614 & 19.5 \\
\hline JUL & $1.18 \pm 0.22$ & $2.65 \pm 0.93$ & $1.23 \pm 0.19$ & 15 & $0.29 \pm 0.11$ & $2.45 \pm 0.58$ & 15 & 201.5 & 617 & 15.9 \\
\hline AUG & $2.03 \pm 1.34$ & $3.61 \pm 1.01$ & $1.31 \pm 0.27$ & 16 & $0.45 \pm 0.24$ & $3.88 \pm 0.94$ & 24 & 68.5 & 648 & 15.9 \\
\hline SEP & $8.66 \pm 4.72$ & $2.52 \pm 0.68$ & $1.44 \pm 0.30$ & 15 & $0.61 \pm 0.40$ & $2.70 \pm 0.55$ & 20 & 237.7 & 722 & \\
\hline OCT & $5.04 \pm 3.44$ & $2.72 \pm 1.14$ & $1.07 \pm 0.24$ & 18 & $0.73 \pm 0.49$ & $2.14 \pm 0.76$ & 10 & 165.2 & 778 & 21.9 \\
\hline NOV & $3.01 \pm 1.88$ & $2.67 \pm 0.62$ & $1.59 \pm 0.67$ & 15 & $0.26 \pm 0.17$ & $3.35 \pm 0.50$ & 10 & 108.8 & 836 & 22.1 \\
\hline DEC & $1.65 \pm 1,56$ & $3.45 \pm 0.93$ & $1.15 \pm 0.29$ & 13 & $0.40 \pm 0.14$ & $3.24 \pm 0.61$ & 16 & 77.9 & 846 & 28.5 \\
\hline JAN & $2.29 \pm 1.84$ & $3.56 \pm 1.33$ & $1.28 \pm 0.35$ & 16 & $0.14 \pm 0.16$ & $3.65 \pm 0.97$ & 21 & 111.8 & 817 & 24.8 \\
\hline FEB & $0.79 \pm 0.62$ & $4.25 \pm 0.57$ & $0.95 \pm 0.28$ & 14 & $0.09 \pm 0.09$ & $3.63 \pm 0.86$ & 8 & 101.1 & 808 & 25.7 \\
\hline MAR & $1.04 \pm 1.05$ & $3.58 \pm 0.71$ & $1.31 \pm 0.54$ & 19 & $0.10 \pm 0.05$ & $3.77 \pm 0.71$ & 15 & 252.1 & 753 & 21.9 \\
\hline
\end{tabular}


Table 2. Spearman correlation test among mean valves of GSI (gonadosomatic index) and rainfall, day length, temperature, SRI (stomach repletion index) and HSI (hepatosomatic index) data from April 2001 to March 2002 for females and males of Bryconamericus iheringii from rio Vacacaí, RS, Brazil.

\begin{tabular}{cccc}
\hline & Sex & $\mathbf{r}_{\mathbf{s}}$ & $\mathbf{p}$ \\
\hline \multirow{2}{*}{ GSI x rainfall } & Females & -0.0070 & 0.9828 \\
& Males & -0.1544 & 0.6319 \\
GSI x day length & Females & 0.3497 & 0.2652 \\
& Males & -0.0421 & 0.8966 \\
GSI x temperature & Females & 0.1553 & 0.6485 \\
& Males & -0.1789 & 0.5987 \\
GSI x SRI & Females & -0.4553 & 0.1369 \\
GSI x HSI & Males & -0.3895 & 0.2108 \\
& Females & 0.3895 & 0.2108 \\
\hline
\end{tabular}

Most individuals of the size classes 1 to 3 belong to the category where hooks were absent (Fig. 4c). Individuals with less developed hooks appeared in small number in the size class 2 , increasing in the size classes 3 and 4 and present until size class 7 . Individuals with developed hooks were abundant among size classes 4 to 9 (in class 9 only one individual was analyzed). The size class 8 presented the highest frequency of males with well-developed hooks, which first appeared in size class class 3 .

\section{Discussion}

A seasonal reproductive period, commonly in spring and summer, and influenced by one or more biotic and/or abiotic factors, is a typical characteristic shared by many Neotropical characiform species (Vazzoler \& Menezes, 1992). Other studies with characid species in Rio Grande do Sul showed a similar reproductive seasonality for many species, such as Serrapinnus calliurus (Gelain et al., 1999), Cheirodon ibicuhiensis (Oliveira et al., 2002), Diapoma speculiferum (Azevedo et al., 2000), Aphyocharax anisitsi (T. Gonçalves, pers. commun.) and Odontostilbe pequira (Oliveira, 2003). In most of these species, the mean values of GSI were significantly and positively correlated with the increase of day length and temperature. The reproductive seasonality of $B$. iheringii is in accordance with the pattern described for most characid species in the subtropical area and, in spite of the absence of statistical correlations, the day length and temperature may have an important role in the reproduction of this species, acting as "starters" of gonadal maturation. Some biotic factors can be also related to reproduction. The values of SRI and HSI indicate that, during the reproductive period, the species tends to feed less in relation to other months. An intense feeding during non-reproductive periods can represent a strategy for energy allocation to reproduction, when these reserves would be used on vitellogenesis (Barbieri et al., 1996).

The spawning type and fecundity (particularly the relative fecundity) are two of the less studied aspects in fish reproduction. Much of the available data on fish fecundity in literature do not take into account the individual's size or weight, or even if the described oocytes number corresponds to the fecundity during the reproductive period or to a single oocytes batch, making comparisons difficult among species. According to Vazzoler (1996), fecundity can be an unstable feature, presenting inter and intra-specific variations, besides latitudinal variability and changes among successive reproductive periods and between individuals with same size in the same reproductive period. Therefore, generalizations regarding fecundity should be made carefully (Vazzoler \& Menezes, 1992).
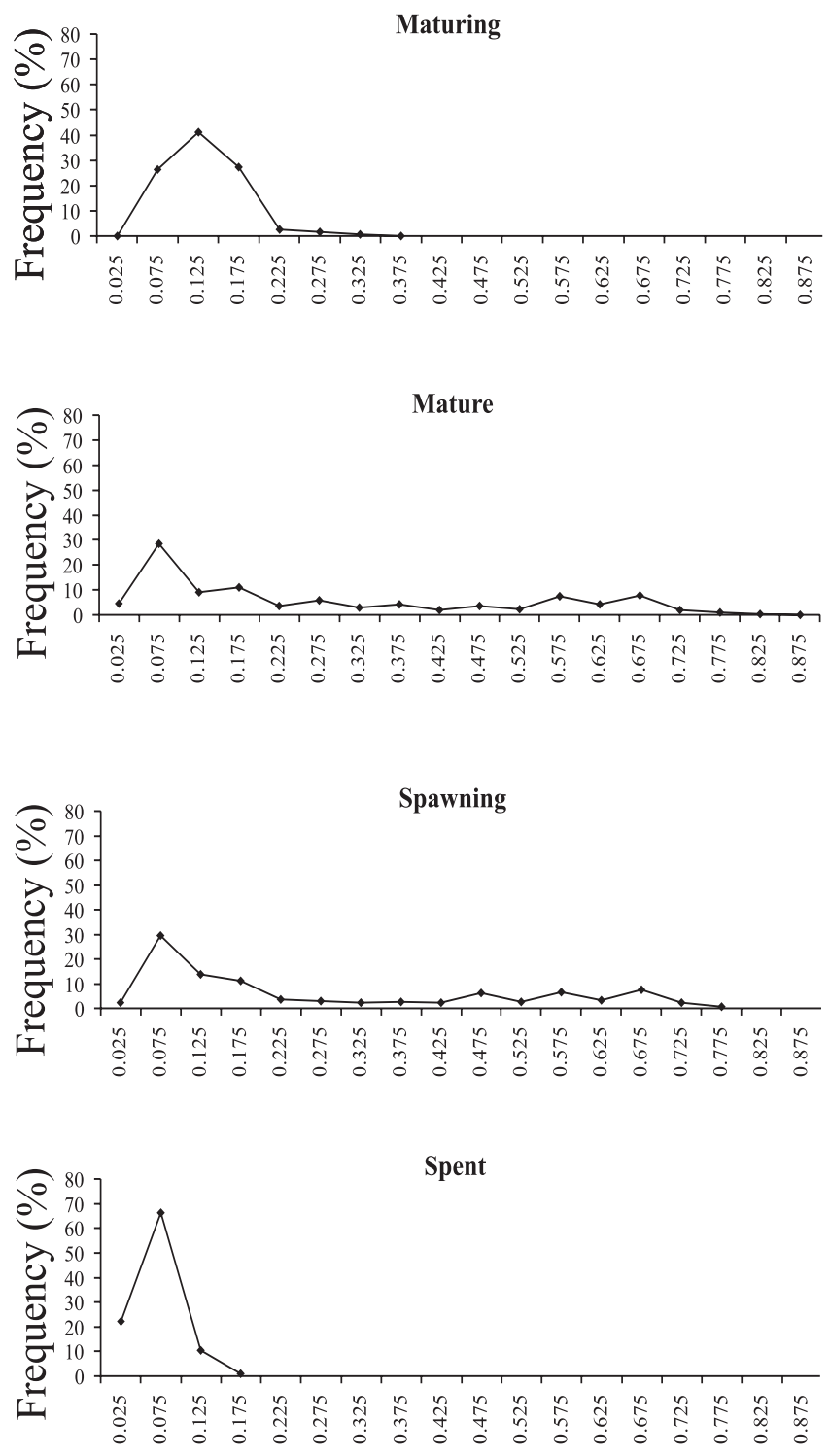

Oocyte length classes

Fig. 3. Distribution of the relative frequencies of oocyte diameter classes in the different gonadal maturation stages in Bryconamericus iheringii from rio Vacacaí, RS, Brazil, between April 2001 and March 2002. Number of analyzed gonads in each stage: maturing (9), mature (6), spawning (8) and spent (8). 


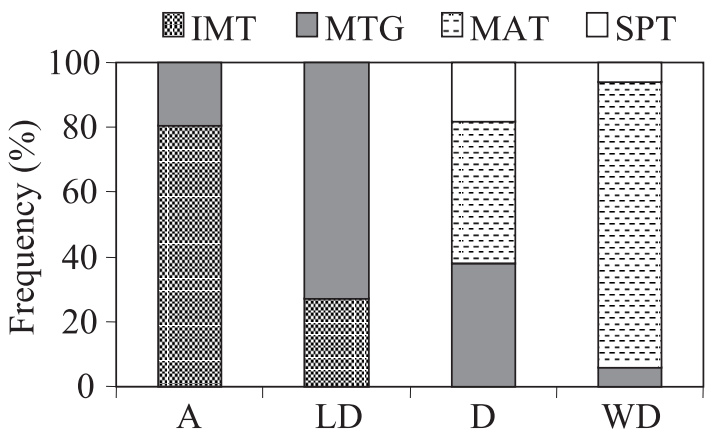

(a) Hooks development stage

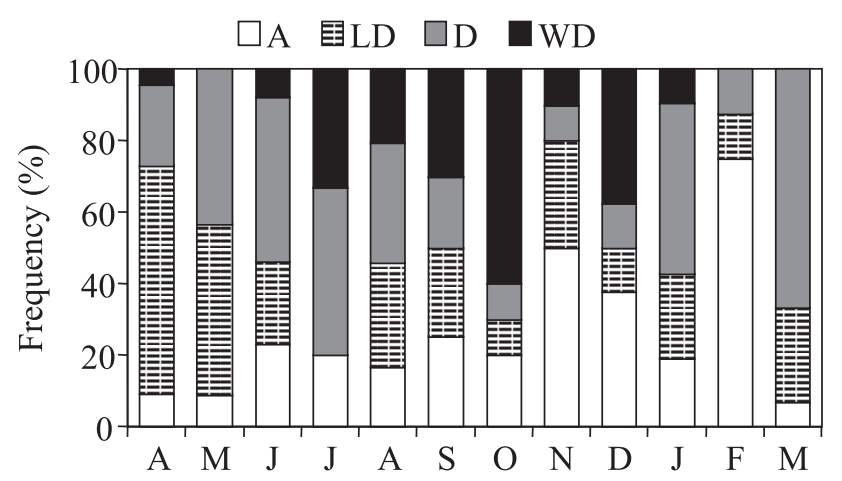

(b)

Months

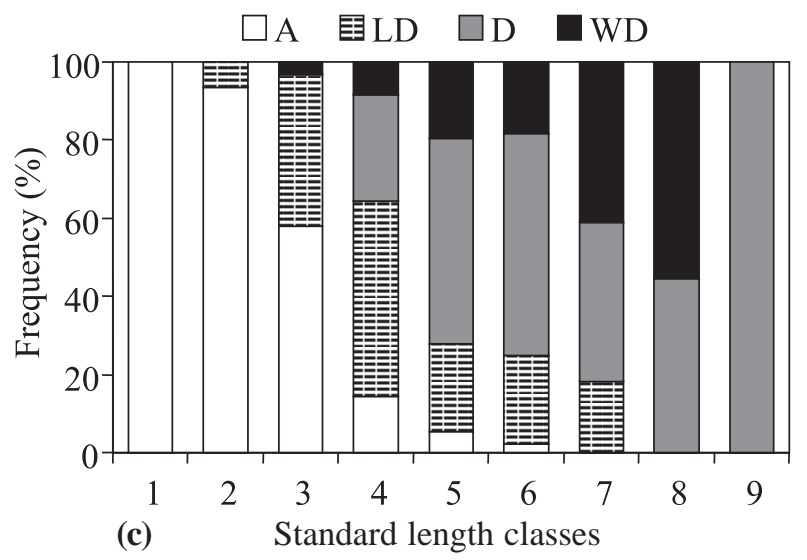

Fig. 4. Frequency of occurrence of hooks (a) by gonadal maturation stages; (b) by month and (c) by standard length classes in males of Bryconamericus iheringii from rio Vacacaí, RS, Brazil, from April/2001 through March/ 2002. $\mathrm{IMT}=$ immature; $\mathrm{MTG}=$ maturing; $\mathrm{MAT}=$ mature; $\mathrm{SPT}=$ spent; $\mathrm{A}=$ absent $\mathrm{LD}=$ less developed; $\mathrm{D}=$ developed; $\mathrm{WD}=$ well developed.

Small characids (less than $10 \mathrm{~cm}$ ), which are externally fertilized, such as Serrapinnus calliurus (Gelain et al., 1999), Cheirodon ibicuhiensis (Oliveira et al., 2002), Odontostilbe pequira (Oliveira, 2003) and Aphyocharax anisitsi (T. Gonçalves, pers. comm.), have higher values of relative fecundity when compared to inseminating species such as Diapoma speculiferum (Azevedo et al., 2000), Mimagoniates rheocharis and M. microlepis (Azevedo, 2000), and
Pseudocorynopoma doriae (F. Melo, pers. comm.). In $B$. iheringii, the absolute and relative fecundities are lower than in members of the family with external fertilization listed above. The relative fecundity, however, was similar to values observed in inseminating species. Species with low fecundity have, frequently, attributes such as parental care, insemination, internal fertilization or multiple spawning, strategies that may increase the chances of fertilization and/or survival of eggs and larvae (Vazzoler \& Menezes, 1992; Azevedo, 2000; Azevedo et al., 2000). According to Malabarba \& Weitzman (2003), the glandulocaudines would form a natural clade within Characidae with several genera previously classified into Tetragonopterinae subfamily (including Bryconamericus), sharing synapomorphies related to the dorsal fin and tooth arrangement. The low fecundity found in B. iheringii and glandulocaudine species (Azevedo, 2000; Azevedo et al., 2000) could be, therefore, a result of common ancestry independent of the presence of insemination or any other character related to parental care.

Relationships between absolute fecundity and standard length, and absolute fecundity and total weight, showed that weight and length are reliable indicators of the capacity of oocyte production once the fecundity increases with the increase of the fish in size and weight. However, the length seems to be a better indicator of the capacity of oocyte production than the weight, because fish does not decrease significantly in size whereas weight may vary along the year (Bagenal, 1967). The gonads weight, however, is a more direct indicator of the capacity of oocyte production of the species, because it showed a linear relation with fecundity, indicating that the two variables increase proportionally.

According to Vazzoler (1996), the spawning type is the way how females release mature oocytes in a reproductive period. Multiple spawning is related to oocyte development "synchronized in more than two groups" in which oocytes of each batch develops simultaneously and are released when they reach total maturation, occurring successive elimination of mature oocyte batches (Vazzoler, 1996). Multiple spawning represents a strategy through which certain species increase the number of oocytes produced in a reproductive period in higher levels than it would be predictable, considering their length. Multiple spawning would demand, however, a higher annual reproductive effort than reached with a single spawning (Burt et al., 1988). Thus, multiple spawning in B. iheringii can represent an adaptative advantage that may increase reproductive success, reflecting in a relatively low oocyte production in each spawning event. The number of oocytes obtained for $B$. iheringii in this study should be understood as the fecundity by oocytes batch and not as the fecundity by reproductive period. Therefore, the multiple spawning could explain the low fecundity values observed.

The presence of hooks on the anal - and pelvic - fin rays of males, often on the caudal fin and rarely on the dorsal and/ or pectoral fins, has been described in Gasteropelecidae, Serrasalminae and in several species of the Characidae (Malabarba \& Weitzman, 2003). These hooks may differ greatly 
in shape, position and possibly function among species of these groups, but they were always observed as bony-spiny processes developed on the surface of individual segments of lepidotrichia (Malabarba \& Weitzman, 2003). These authors hypothesize that these hooks represents an expression of a gene or genes absent in other American or African Characiformes, as in Siluriformes and Cypriniformes. This fact suggests that the presence of fin hooks is a derived character and a synapomorphy for certain subgroups of Characiformes. The real function of the fin ray hooks is still unknown and according to Wiley \& Collette (1970) these structures may work as contact organs to keep male and female close to each other during spawning movements. Azevedo (2000), studying two Glandulocaudinae species, suggests that these structures can be related to their courtship behavior. Garutti (1990) and von Ihering \& Azevedo (1936) affirmed that the occurrence of hooks in A. bimaculatus is seasonal, coinciding with the reproductive period, being lost when it is over. On the other hand, Andrade et al. (1984) studied the same species and concluded that the hooks are a constant characteristic in adult males. Azevedo (2000) studying two Glandulocaudinae species, Mimagoniates microlepis and M. rheocharis, suggested that these characters are not lost, once they could be found in males after the reproduction. In B. iheringii, it was observed that males with well developed hooks were frequent during the reproductive period, decreasing in frequency in subsequent months. This can be attributed not to the loss of hooks, but to the recruitment of young male individuals in the population. As mature males without hooks or with less developed hooks were not found, we suggest that the hooks are not lost after reproduction. In individuals of larger length classes, well-developed hooks are always present, even after the reproductive period. However, we observed males with and without hooks in intermediate length classes. Thus, the development of fin ray hooks seems to be related not directly to the increase in the individual's body size but more to the gonadal development and maturation.

\section{Acknowledgements}

To the colleagues of the Laboratório de Ictiologia, UFRGS for their help in field and laboratory work; to Luiz R. Malabarba for reviewing this manuscript and Leonardo Gubert for helping with corrections on the English text. To CNPq (proc.464545/00-5 and 476821/2003-7) and CAPES.

\section{Literature Cited}

Adebisi, A. A. 1987. The relationships between fecundities, gonadosomatic indices and egg sizes of some fishes of Ogun River, Nigeria. Archiv fuer Hydrobiologie, 111:151156.

Andrade, D. R., E. Menin \& S. P. Ribeiro. 1984. Periodicidade da característica sexual secundária em Astyanax bimaculatus (Linnaeus, 1758) Pisces, Characidae. Revista Seiva, 44(93):9-12.
Azevedo, M. A. 2000. Biologia reprodutiva de dois glandulocaudíneos com inseminação, Mimagoniates microlepis e Mimagoniates rheocharis (Teleostei: Characidae), e características de seus ambientes. Unpublished M. Sc. Dissertation, Universidade Federal do Rio Grande do Sul, Porto Alegre, Brazil. 84p.

Azevedo, M. A., L. R. Malabarba \& C. B. Fialho. 2000. Reproductive biology of the inseminated Glandulocaudine Diapoma speculiferum Cope (Actinopterygii: Characidae). Copeia, 2000(4):983-989.

Bagenal, T. B. 1967. A short review of fish fecundity. p. 89111, In: Shelby, D. Gergink (ed.). The biological basis of freshwater fish production. Blackwell, Oxford.

Barbieri, G., S. M. Hartz \& J. R. Verani. 1996. O fator de condição e índice hepatossomático como indicadores do período de desova de Astyanax fasciatus da represa do Lobo, São Paulo (Osteichthyes, Characidae). Iheringia, Sér. Zool. (81):97-100.

Britski, H. A., Y. Sato \& A. B. S. Rosa. 1988. Manual de Identificação de Peixes da Região de Três Marias, com chave e identificação para os peixes da bacia do rio São Francisco. Brasília, Ed. Ministério da Irrigação-CODEVASF, $3^{a}$ ed., 115p.

Burt, A., D. L. Kramer, K. Nakatsuru \& C. Spry. 1988. The tempo of reproduction in Hyphessobrycon pulchripinnis (Characidae), with a discussion on the biology of "multiple spawning" in fishes. Environmental Biology of fishes, 22(1):15-27.

Garutti, V. 1990. Caráter sexual secundário em Astyanax bimaculatus (Ostariophysi, Characidae) relacionado às nadadeiras anal e pélvicas. Naturalia, 15:109-119.

Gelain, D., C. B. Fialho \& L. R. Malabarba. 1999. Biologia reprodutiva de Serrapinnus calliurus (Characidae, Cheirodontinae) do arroio Ribeiro, Barra do Ribeiro, Rio Grande do Sul, Brasil. Comunicações do Museu de Ciência e Tecnologia, PUCRS, Sér. Zool., 12:71-82.

von Ihering, R. \& P. Azevedo. 1936. As piabas dos açudes nordestinos (Characidae: Tetragonopterinae). Archivos do Instituto Biológico de São Paulo, 7:75-106.

Malabarba, L. R. \& S. H. Weitzman. 2003. Description of a new genus with six new species from southern Brazil, Uruguay and Argentina, with a discussion of a putative Characid clade (Teleostei: Characiformes: Characidae). Comunicações do Museu de Ciência e Tecnologia, PUCRS, Sér. Zool., 16(1):67-151.

Oliveira, C. L. C. 2003. Análise comparada de caracteres reprodutivos e da glândula branquial de duas espécies de Cheirodontinae (Teleostei: Characidae). Unpublished M.Sc. Dissertation, Universidade Federal do Rio Grande do Sul, Porto Alegre, Brasil. 80p.

Oliveira, C. L. C., C. B. Fialho \& L. R. Malabarba. 2002. Período reprodutivo, desova e fecundidade de Cheirodon ibicuhiensis Eigenmann, 1915 (Ostariophysi: Characidae) do arroio Ribeiro, Rio Grande do Sul, Brasil. Comunicações do Museu de Ciência e Tecnologia, PUCRS, Sér. Zool. 15(1):3-14. 
Reis, R. E., S. O. Kullander \& C. J. Ferraris Jr. (eds.). 2003. Check list of freshwater fishes of South and Central America. EDIPUCRS, Porto Alegre, 742p.

Santos, E. P. dos. 1978. Dinâmica de populações aplicada à pesca e piscicultura. São Paulo, Hucitec, Editora da Universidade de São Paulo. 129 p.

Silva, J. F. P. 1998. Revisão taxonômica das espécies de Bryconamericus (Eigenmann, 1907) do Sul e Sudeste do Brasil (Ostariophysi: Characidae). Unpublished M. Sc. Dissertation, Pontifícia Universidade Católica do Rio Grande do Sul, Porto Alegre, 107p.

Suzuki, H. I. \& A. A. Agostinho. 1997. Reprodução de peixes do reservatório de Segredo. p. 163-181. In: Agostinho, A.A. \& Gomes, L.C. (Ed.). Reservatório de segredo: Bases ecológicas para o manejo. Maringá, EDUEM. 387p.

Vari, R. P. \& D. J. Siebert. 1990. A new unusually sexually dimorphic species of Bryconamericus (Pisces:
Ostariophysi: Characidae) from the Peruvian Amazon. Proceedings of the Biological Society of Washington, 103(3):516-524.

Vazzoler, A. E. A. M. \& N. A. Menezes. 1992. Síntese de conhecimentos sobre o comportamento reprodutivo dos Characiformes da América do Sul (Teleostei, Ostariophysi). Revista Brasileira de Biologia, 52(4):627640.

Vazzoler, A. E. A. M. 1996. Biologia da reprodução de peixes teleósteos: teoria e prática. Maringá, EDUEM. 169p.

Wiley, M. L. \& B. B. Collette. 1970. Breeding tubercles and contact organs in fishes, their occurrence, structure, and significance. Bulletin of the American Museum of Natural History, 143(3):145-216.

Received May 2004 Accepted November 2004 